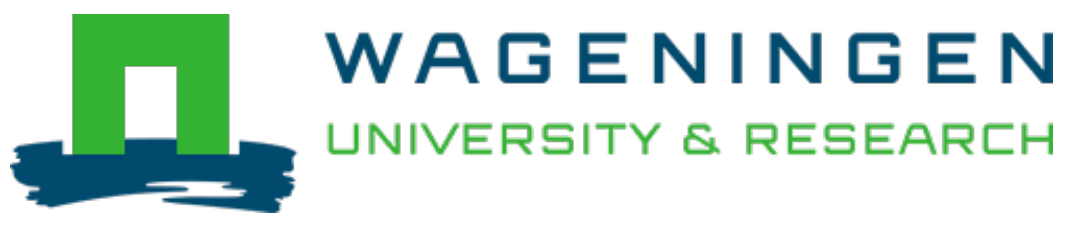

\author{
Importance of elasticity on calcium caseinate fiber formation \\ Food Structure \\ Wang, Zhaojun; Bei, Tian; Karleen, Saffiera; Goot, Atze Jan; Chen, Jie \\ https://doi.org/10.1016/j.foostr.2020.100171
}

This publication is made publicly available in the institutional repository of Wageningen University and Research, under the terms of article $25 \mathrm{fa}$ of the Dutch Copyright Act, also known as the Amendment Taverne. This has been done with explicit consent by the author.

Article $25 \mathrm{fa}$ states that the author of a short scientific work funded either wholly or partially by Dutch public funds is entitled to make that work publicly available for no consideration following a reasonable period of time after the work was first published, provided that clear reference is made to the source of the first publication of the work.

This publication is distributed under The Association of Universities in the Netherlands (VSNU) 'Article $25 \mathrm{fa}$

implementation' project. In this project research outputs of researchers employed by Dutch Universities that comply with the legal requirements of Article $25 \mathrm{fa}$ of the Dutch Copyright Act are distributed online and free of cost or other barriers in institutional repositories. Research outputs are distributed six months after their first online publication in the original published version and with proper attribution to the source of the original publication.

You are permitted to download and use the publication for personal purposes. All rights remain with the author(s) and / or copyright owner(s) of this work. Any use of the publication or parts of it other than authorised under article $25 \mathrm{fa}$ of the Dutch Copyright act is prohibited. Wageningen University \& Research and the author(s) of this publication shall not be held responsible or liable for any damages resulting from your (re)use of this publication.

For questions regarding the public availability of this publication please contact openscience.library@,wur.nl 


\title{
Importance of elasticity on calcium caseinate fiber formation
}

\author{
Zhaojun Wang ${ }^{\mathrm{a}}$, Bei Tian ${ }^{\mathrm{b}}$, Saffiera Karleen ${ }^{\mathrm{c}}$, Atze Jan van der Goot ${ }^{\mathrm{d}}$, Jie Chen ${ }^{\mathrm{a}, *}$ \\ ${ }^{a}$ State Key Laboratory of Food Science and Technology, Jiangnan University, Wuxi, 214122, China \\ ${ }^{\mathrm{b}}$ Food \& Biobased Research, Wageningen University \& Research, PO Box 17, 6700AA, Wageningen, the Netherlands \\ ${ }^{\mathrm{c}}$ Business Development SFS, CORBION, PO Box 21, 4200AA, Gorinchem, the Netherlands \\ ${ }^{\mathrm{d}}$ Food Process Engineering, Wageningen University \& Research, PO Box 17, 6700AA, Wageningen, the Netherlands
}

\section{A R T I C L E I N F O}

\section{Keywords}

Calcium caseinate

Elasticity

$\mathrm{D} 2 \mathrm{O}$

Air bubble

Anisotropy

\begin{abstract}
A B S T R A C T
This study aims to gain a better understanding of the structuring mechanisms in rollerdried calcium caseinate by using $\mathrm{H} 2 \mathrm{O}$ and D $2 \mathrm{O}$ as protein solvents. Calcium caseinate mixed with $\mathrm{H} 2 \mathrm{O}$ gives a layered material, while the use of D $2 \mathrm{O}$ results in a fibrous material. The D $2 \mathrm{O}$ hydrated protein network is more elastic and can hold more air, which could contribute to the fibrous appearance and a greater mechanical anisotropy of the sheared material. These results highlighted that the elasticity of the calcium caseinate dispersion is important for stabilising air bubbles upon shear deformation, which is expected to play a major role in the fibre formation of calcium caseinate.
\end{abstract}

\section{Introduction}

The creation of fibre structures within proteins is of great relevance, as these structures are promising candidates for the next generation of meat analogues. A novel technology based on well-defined shear flow was introduced to create fibrous structures from calcium caseinate (Manski, van der Goot, \& Boom, 2007b,c) and plant proteins, such as soy protein (Dekkers, Nikiforidis, \& van der Goot, 2016) and pea protein (Schreuders et al., 2019). With regards to the meat-like structures, the fibrousness of calcium caseinate material is much more pronounced than those of plant proteins. To better translate the results obtained from calcium caseinate to plant proteins, it is important to investigate the mechanism of fibre formation in calcium caseinate.

The first step towards understanding is a quantitative description of the structures formed. Tensile tests were used to characterise the mechanical properties, while confocal scanning laser microscopy and scanning electron microscopy (SEM) revealed structure at micro- and nanoscale (Manski, van der Zalm, van der Goot, \& Boom, 2008; Wang, Dekkers, Boom, \& van der Goot, 2019; Wang, Tian, Boom, \& van der Goot, 2019a). X-ray tomography (XRT) was used to described void fractions and air bubble shapes, while spin-echo small angle neutron scattering provides complimentary information to XRT (Tian, Wang, van der Goot, \& Bouwman, 2018; Wang, Dekkers, \& van der Goot, 2020; Wang, Tian, Boom, \& van der Goot, 2019b). More recent small angle neutron scattering turned out to be a promising method to quantify the orientation and anisotropy of the fibres down to $100 \mathrm{~nm}$ (Tian et al., 2020). In these neutron scattering techniques, $\mathrm{D}_{2} \mathrm{O}$ rather than $\mathrm{H}_{2} \mathrm{O}$ is often used as a solvent to enhance the contrast between protein and solvent (Lopez-Rubio \& Gilbert, 2009; Tromp \& Bouwman, 2007). Generally, it is assumed that the replacement of $\mathrm{H}_{2} \mathrm{O}$ by $\mathrm{D}_{2} \mathrm{O}$ has limited effect on the protein structure (Bouchoux et al., 2015). However, we found that the roller-dried calcium caseinate fibre formation was strongly influenced by the solvent isotope effect (Tian, Garcia Sakai, Pappas, van der Goot, \& Bouwman, 2019; Tian et al., 2018). Shearing $30 \mathrm{wt} \%$ roller-dried calcium caseinate gave more anisotropic fibres with more deformed air bubbles after replacing $\mathrm{H}_{2} \mathrm{O}$ with $\mathrm{D}_{2} \mathrm{O}$.

A possible explanation for the solvent isotope effect is that proteins become more compact in $\mathrm{D}_{2} \mathrm{O}$ than that in $\mathrm{H}_{2} \mathrm{O}$ (Cioni \& Strambini, 2002; Efimova, Haemers, Wierczinski, Norde, \& van Well, 2007; Sasisanker, Oleinikova, Weingärtner, Ravindra, \& Winter 2004). Gelatin gels in $\mathrm{D}_{2} \mathrm{O}$ are more rigid than those gels in $\mathrm{H}_{2} \mathrm{O}$ (Oakenfull \& Scott, 2003). Besides, $\mathrm{D}_{2} \mathrm{O}$ can promote the self-association of several proteins, such as $\beta$-casein (Evans, Phillips, \& Jones, 1979) and tubulin (Chakrabarti, Kim, Gupta, Barton, \& Himes, 1999). The mechanism is attributed to the enhancement of hydrophobic interactions and stronger hydrogen bonds in $\mathrm{D}_{2} \mathrm{O}$ than in $\mathrm{H}_{2} \mathrm{O}$ (Efimova et al., 2007; Sheu, Schlag, Selzle, \& Yang, 2008; Tian et al., 2019).

Here, we studied the mechanism of fibre formation in roller-dried calcium caseinate by taking advantage of the different properties of $\mathrm{H}_{2} \mathrm{O}$ and $\mathrm{D}_{2} \mathrm{O}$ as protein solvents. The sheared materials were prepared

\footnotetext{
* Corresponding author.

E-mail address: chenjie@jiangnan.edu.cn (J. Chen).
} 
in a shear cell device with roller-dried calcium caseinate dispersion, in which $\mathrm{H}_{2} \mathrm{O}$ was partially or fully replaced with $\mathrm{D}_{2} \mathrm{O}$. The resulting structures of protein and air phase were investigated with SEM and XRT, respectively. The mechanical properties of the materials were determined with a texture analyser. Further, the linear viscoelastic behaviour of the calcium caseinate dispersions was characterised using smallamplitude oscillatory shear measurement. It should be noted that $\mathrm{D}_{2} \mathrm{O}$ is used as a route to investigate the importance of protein-solvent interactions, but we do not advocate it as a food solution.

\section{Materials and methods}

\subsection{Materials}

Roller-dried calcium caseinate powder was kindly provided by DMV International (Veghel, the Netherlands). The calcium caseinate powder (dry base) contained at least $88 \mathrm{wt} \%$ protein and $1.20 \mathrm{wt} \%$ calcium according to the manufacturer's specifications. The dry matter content of the calcium caseinate powder was $93.5 \mathrm{wt} \%$. Heavy water (Deuterium Oxide, $\mathrm{D}_{2} \mathrm{O}, \rho=1.107 \mathrm{~g} \cdot \mathrm{mL}^{-1}$ ) with $99.9 \%$ atom $\% \mathrm{D}$ was purchased from Sigma-Aldrich. The conductivity of demineralized water $\left(\mathrm{H}_{2} \mathrm{O}\right)$ and heavy water $\left(\mathrm{D}_{2} \mathrm{O}\right)$ were 0.36 and $2.92 \mu \mathrm{S} / \mathrm{cm}$, respectively. All other chemicals used for microscopy were of reagent grade (Sigma-Aldrich).

\subsection{Sample preparation in the shear cell device}

Protein dispersions were prepared by manually mixing $30 \mathrm{~g}$ calcium caseinate powder with $70 \mathrm{~g}$ demineralized water $\left(100 \% \mathrm{H}_{2} \mathrm{O}\right), 35 \mathrm{~g}$ demineralized water +38.9 g heavy water $\left(50 \% \mathrm{v} / \mathrm{v} \mathrm{H}_{2} \mathrm{O}+50 \% \mathrm{v} / \mathrm{v}\right.$ $\left.\mathrm{D}_{2} \mathrm{O}\right)$ or $77.7 \mathrm{~g}$ heavy water $\left(100 \% \mathrm{D}_{2} \mathrm{O}\right)$. Each dispersion was transferred to a pre-heated $\left(50^{\circ} \mathrm{C}\right)$ shear cell device with gap angle of $2.5^{\circ}$ (Wageningen University, the Netherlands). More details of the shear cell device is described in an earlier publication (Van der Zalm, Berghout, van der Goot, \& Boom, 2012). The shear process was carried out at a rotating speed of $150 \mathrm{rpm}$ for $5 \mathrm{~min}$. After shearing, the materials were cooled down to $4{ }^{\circ} \mathrm{C}$ within $10 \mathrm{~min}$ before the cell was opened. Tensile tests were performed on materials within $1 \mathrm{~h}$ after removal from the device. Other samples were stored at $-20^{\circ} \mathrm{C}$ until further analysis. Each material was prepared and analysed twice independently.

\subsection{Tensile strength analysis}

A texture analyser (Instron Testing System, table model 5564) was used with a load cell of $100 \mathrm{~N}$. A dog-bone-shaped mould was used to cut samples for the tensile test. The samples were $15.2 \mathrm{~mm}$ long and 3.18 $\mathrm{mm}$ wide; the thickness varied between 4 and $6 \mathrm{~mm}$. The samples were parallel or perpendicular to the shear flow (based on the shear-vorticity plane). The tensile tests were conducted at a constant deformation speed of $3 \mathrm{~mm} / \mathrm{s}$. Grips with abrasive paper were used to prevent slipping during testing. At least two specimens per direction were measured. The results obtained from these tensile tests were depicted as force-displacement curves. The true stress $(\sigma, \mathrm{kPa})$ and Hencky strain $(\varepsilon,-)$ were calculated. The point at which a dramatic decrease in stress in the stress-strain curve was observed, was taken as the point of fracture, at which we measured the fracture stress $(\sigma, \mathrm{kPa})$ and fracture strain $(\varepsilon,-)$. The ratio of the average data for mechanical properties measured in the parallel and perpendicular directions to the shear flow were calculated and used as an indication of the mechanical anisotropy of the sample.

\subsection{X-ray tomography}

The void fraction and geometry of air bubbles in the sheared materials were studied by X-ray tomography. Samples were scanned with a GE Phoenix v|tome|x m tomographer (General Electric, Wunstorf, Germany) set at $80 \mathrm{kV} / 90 \mu \mathrm{A}$. The system contains two X-ray sources; the $240 \mathrm{kV}$ micro-focus tube with a tungsten target was used. The images were recorded by a GE DXR detector array with $2024 \times 2024$ pixels (pixel size, $200 \mu \mathrm{m}$ ). The detector and object were located $815 \mathrm{~mm}$ and $28.55 \mathrm{~mm}$ from the X-ray source, respectively, resulting in a spatial resolution of $7.00 \mu \mathrm{m}$. A full scan consists of 750 projections over $360^{\circ}$. The first image was skipped; images $2-4$ were averaged into one projection. GE reconstruction software (Wunstorf, Germany) was used to calculate the 3D structure via back projection. The 3D images were analysed using Avizo imaging software version 9.3.0. Three samples of each material were measured.

\subsection{Scanning electron microscopy}

The sheared materials were torn apart manually along the shear flow direction $(\sim 2 \mathrm{~mm}$, based on the shear flow-vorticity plane), and rinsed with demineralized water. Subsequently, the samples were fixated in a solution of glutaraldehyde $(1.25 \% \mathrm{v} / \mathrm{v})$ and formaldehyde $(1.25 \% \mathrm{v} / \mathrm{v})$ in a vacuum chamber for overnight. Follow by, the fixed samples were dehydrated in a graded series of ethanol solutions $(10 \%, 30 \%, 50 \%$, $70 \%, 90 \%$ and $100 \% \mathrm{v} / \mathrm{v}, 20 \mathrm{~min}$ each). Critical point drying with carbon dioxide (CPD 300, Leica, Vienna, Austria) was performed. The dried samples were then glued to sample holders using conductive carbon cement (Leit-C, Neubauer Chemicalien, Germany), and sputtercoated with $15 \mathrm{~nm}$ of iridium (EM QSG100, Leica, Vienna, Austria). The surface was analysed with a field emission scanning electron microscope (Magellan 400, FEI, Eindhoven, the Netherlands) at a magnification of 100,000 times at a working distance of 4-6 mm, with secondary electron detection at $2 \mathrm{kV}$ and $6.3 \mathrm{~Pa}$.

\subsection{Rheology}

To carefully measure the rheological properties of the calcium caseinate premixes, a slightly different sample preparation was performed. Main reason was that remaining air bubbles will strongly influence the rheological measurement. Previous experiments revealed that slight heating helps to remove most of the air, but it does not change the structuring properties (Wang et al., 2019a). Calcium caseinate premixes were prepared at $70^{\circ} \mathrm{C}$ for $15 \mathrm{~min}$ to obtain homogeneous dispersions. Care was taken to remove any air. The mixtures were kept at $50{ }^{\circ} \mathrm{C}$ prior to the rheological measurements. Strain sweep measurements within a strain range of $0.1-100 \%$ were performed at $6.28 \mathrm{rad} / \mathrm{s}$ to determine the linear viscoelastic region at $50{ }^{\circ} \mathrm{C}$ using a Paar MCR 301 rheometer (Anton Paar, Graz, Austria) with serrated parallel plate geometry (diameter $25 \mathrm{~mm}$, gap $1 \mathrm{~mm}$ ). Frequency sweeps were performed at a constant strain of $1 \%$ (based on strain amplitude sweeps) within an angular frequency $(\omega)$ range of $0.1-62.8 \mathrm{rad} / \mathrm{s}$. The samples were covered with silicone oil to reduce water evaporation and rested for $1 \mathrm{~min}$ before testing.

\section{Results and discussion}

\subsection{Structure formation}

Fig. 1 shows the materials obtained after shearing $30 \mathrm{wt} \%$ dense calcium caseinate dispersion made of different solvents, namely $100 \%$ $\mathrm{H}_{2} \mathrm{O}, 50 \% \mathrm{D}_{2} \mathrm{O}$ and $100 \% \mathrm{D}_{2} \mathrm{O}$. With only $\mathrm{H}_{2} \mathrm{O}$ in the calcium caseinate dispersion, a layered material was obtained after shearing at $150 \mathrm{rpm}$ for 5 min (Fig. 1A). This material did not show any detached fibres upon tearing. Partially or full replacement of $\mathrm{H}_{2} \mathrm{O}$ with $\mathrm{D}_{2} \mathrm{O}$ in calcium caseinate dispersions resulted in fibrous materials, demonstrated by isolated thin fibres after tearing (Fig. $1 \mathrm{~B}$ and C1). The use of $\mathrm{D}_{2} \mathrm{O}$ led to expelled water during shearing. When prepared with $100 \% \mathrm{D}_{2} \mathrm{O}$, some large holes were present in the material as displayed in Fig. 1C2 (based on the velocity gradient-vorticity plane).

The inclusion of air of the sheared material was analysed with X-ray tomography (XRT) (Figs. 2 and 3). It is obvious that the calcium caseinate material made with $\mathrm{H}_{2} \mathrm{O}$ contained the lowest air inclusion 

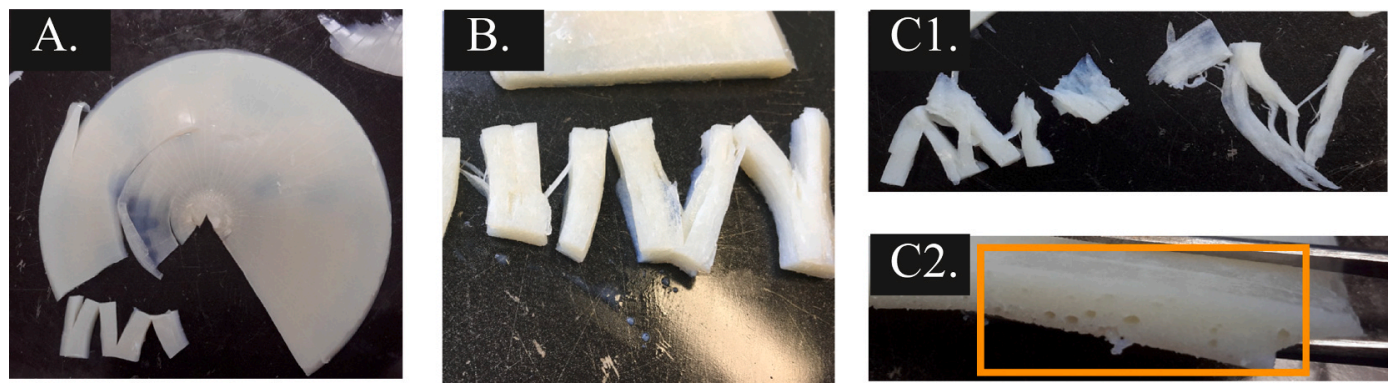

Fig. 1. Macrostructure of sheared $30 \mathrm{wt} \%$ calcium caseinate dispersions made of (A) $100 \% \mathrm{H}_{2} \mathrm{O}$, (B) $50 \% \mathrm{D}_{2} \mathrm{O}$ and (C) $100 \% \mathrm{D}_{2} \mathrm{O}$; (C1) material after tearing; (C2) cross section of the material in the velocity gradient-vorticity plane.

$100 \% \mathrm{H}_{2} \mathrm{O}$

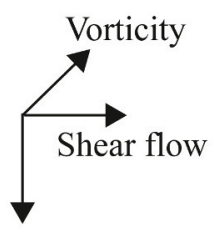

Velocity gradient

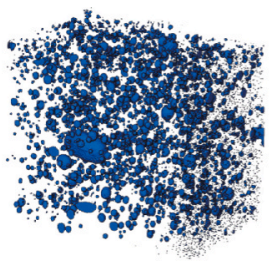

$50 \% \mathrm{D}_{2} \mathrm{O}$

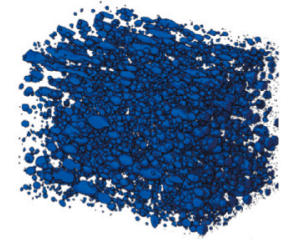

$100 \% \mathrm{D}_{2} \mathrm{O}$

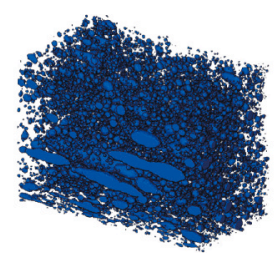

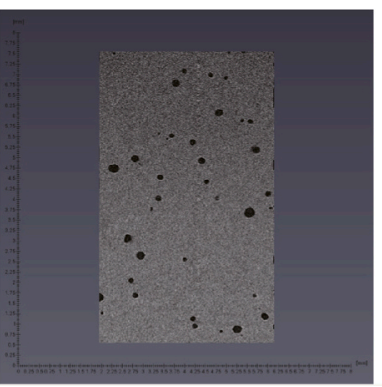
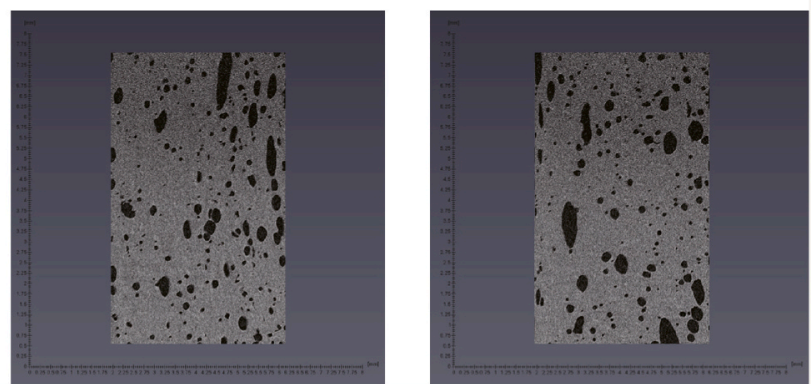

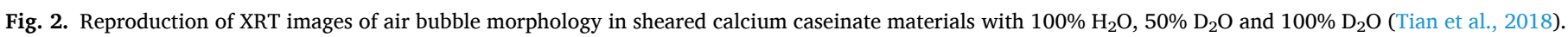

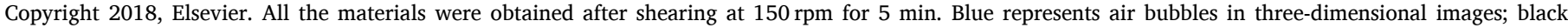

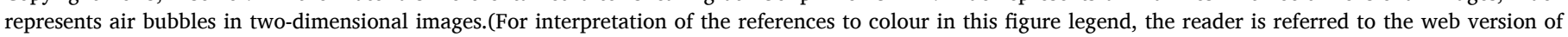
this article.)

levels $(2.6 \pm 0.5 \%, \mathrm{v} / \mathrm{v})$. The air bubbles are small $\left(<0.01 \mathrm{~mm}^{3}\right)$ and spherical in shape. The use of $50 \%$ and $100 \% \mathrm{D}_{2} \mathrm{O}$ largely increased the air inclusion level to $15.1 \pm 1.3 \%(\mathrm{v} / \mathrm{v})$ and $13.8 \pm 2.3 \%(\mathrm{v} / \mathrm{v})$, respectively. These materials mainly contained large $\left(>0.01 \mathrm{~mm}^{3}\right)$ and elliptical air bubbles. Those results are in line with previous study using XRT data and neutron refraction model in which it was shown that large air bubbles in sheared materials were deformed and aligned in the shear flow direction when $\mathrm{D}_{2} \mathrm{O}$ was present in the material (Tian et al., 2018). According to the neutron refraction data, the degree of deformation of air bubble in $50 \%$ and $100 \% \mathrm{D}_{2} \mathrm{O}$ samples ( 0.23 and 0.25 ) had no significant difference (Tian et al., 2018), suggesting that air bubbles in these two samples have a similar degree of anisotropic.

The SEM images in Fig. 4 show the microstructure of sheared material with $100 \% \mathrm{H}_{2} \mathrm{O}, 50 \% \mathrm{D}_{2} \mathrm{O}$ and $100 \% \mathrm{D}_{2} \mathrm{O}$. No protein alignment at a submicron scale was achieved in these samples. This indicated that the presence of $\mathrm{D}_{2} \mathrm{O}$ in roller-dried calcium caseinate had little effect on the alignment of the aggregates at the submicron length scale in the flow direction.

\subsection{Tensile properties}

As described in the previous section, the use of $\mathrm{H}_{2} \mathrm{O}$ yielded a layered structure, while the use of $\mathrm{D}_{2} \mathrm{O}$ promoted fibre formation at the macroscale (Fig. 1). These materials were subjected to tensile analysis parallel and perpendicular to the shear flow direction. The ratio of the stress $\sigma$ or strain $\varepsilon$ in the parallel and perpendicular directions was used as an index for anisotropy. In the absence of $\mathrm{D}_{2} \mathrm{O}$, the sheared material showed slight anisotropy with an index of 2.0 and 1.3 for $\sigma$ and $\varepsilon$, respectively (Fig. 5). This anisotropic index of $\sigma$ and $\varepsilon$ increased to 4.6 and 2.2 when $50 \%$ of $\mathrm{D}_{2} \mathrm{O}$ was used. There was no significant difference on the anisotropic index between the material with $50 \%$ and $100 \% \mathrm{D}_{2} \mathrm{O}$. The use of $\mathrm{D}_{2} \mathrm{O}$ enhanced the strength of materials in the parallel direction but weakened in the perpendicular direction. In both directions, the high porosity indeed decreased the strength of the materials (Fig. 2), but expelled water during shearing resulted in higher dry matter content that also enhances it. Thus, the large difference between parallel and perpendicular direction could be attributed to the anisotropic morphology of air bubbles in these materials. The large and deformed air bubbles work as a weak phase in the perpendicular direction, which promotes crack propagation along the fibre direction.

\subsection{Rheological properties}

Fig. 6 depicts the frequency dependency of storage modulus $G^{\prime}$, loss modulus $G^{\prime \prime}$ and tangent of phase shift $\tan \delta\left(G^{\prime \prime} / G^{\prime}\right)$ of calcium caseinate dispersions with $100 \% \mathrm{H}_{2} \mathrm{O}, 50 \% \mathrm{D}_{2} \mathrm{O}$ and $100 \% \mathrm{D}_{2} \mathrm{O}$ measured at $50{ }^{\circ} \mathrm{C}$. 


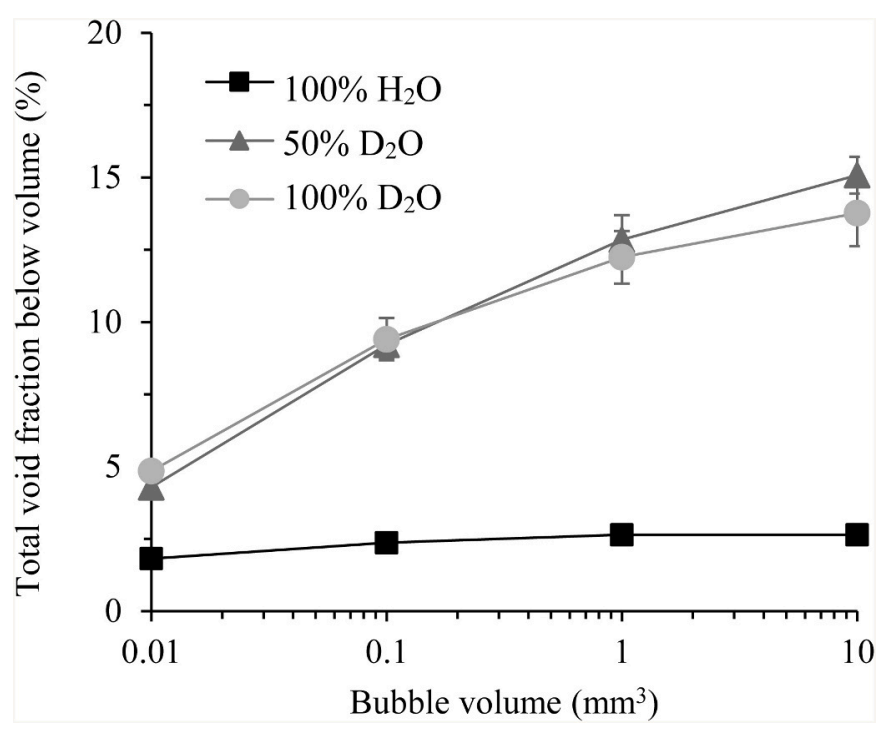

Fig. 3. Overall cumulative void fractions (as the void fraction below the bubble volume in $\mathrm{mm}^{3}$ ). The error bars for the total void fraction below volume are \pm standard deviation; where not shown they were smaller than the marker used.

Fig. $6 \mathrm{~A}$ shows that the use of $\mathrm{D}_{2} \mathrm{O}$ in calcium caseinate resulted in increased values of $G^{\prime}$ at low frequency range $(0.1<\omega<10 \mathrm{rad} / \mathrm{s})$ and less frequency dependency of $G^{\prime \prime}$. All dense calcium caseinate dispersions show crossovers of $G^{\prime}$ and $G^{\prime \prime}(\tan \delta=1)$ at measured frequency range, except for the dispersion with $100 \% \mathrm{D}_{2} \mathrm{O}$ which had a crossover at a lower frequency of $0.25 \mathrm{rad} / \mathrm{s}$ (data not shown). The inverse of the frequency at the crossover is defined as the terminal relaxation time $(\tau)$.
The $\tau$ increased with the use of $\mathrm{D}_{2} \mathrm{O}$, indicating that calcium caseinate dispersion with $\mathrm{D}_{2} \mathrm{O}$ has much stronger physical interactions. This is most likely caused by the enhancement of hydrophobic interactions and hydrogen bonding (Efimova et al., 2007; Sheu et al., 2008; Tian et al., 2019). Previously, differences in relaxation time were used to explain differences in structuring behaviour of spray dried sodium caseinate and calcium caseinate (Manski, van Riemsdijk, Boom, \& van der Goot, 2007). Calcium caseinate had a higher relaxation time. This longer relaxation time implied that upon shearing, microstructural changed could be induced in calcium caseinate, while not in sodium caseinate at moderate shear rates. Here, the use of $\mathrm{D}_{2} \mathrm{O}$ led to increased relaxation time as well and led to similar outcomes with respect to fibre formation. The $\tan \delta$ decreased with increasing $\mathrm{D}_{2} \mathrm{O}$ concentration through the measured frequency range, indicating that $\mathrm{D}_{2} \mathrm{O}$ promoted the elasticity of the material (Fig. 6B). This may be related to more compact and rigid protein particles, which results in a more 'entangled' calcium caseinate dispersion.

A previous study found that the addition of maltodextrin in rollerdried calcium caseinate could stabilise air bubbles upon shear deformation. The explanation was that maltodextrin increased the viscosity and created a more elastic network. Here, we see a similar trend for the elasticity when using $\mathrm{D}_{2} \mathrm{O}$, but not for the viscosity. The viscosity of dispersions with $50 \%$ and $100 \% \mathrm{D}_{2} \mathrm{O}$ was lower (82 and $128 \mathrm{~Pa} \cdot \mathrm{s}$ ) than that with $\mathrm{H}_{2} \mathrm{O}(474 \mathrm{~Pa} \cdot \mathrm{s})$ at a shear rate of $10 \mathrm{~s}^{-1}$. It is likely that the elasticity of the matrix plays a more important role in air holdup than the viscosity. A similar effect has been reported in the dough systems: the elasticity of dough could help to maintain the thickness of solid phase between bubbles upon deformation, and thus would suppress coalescence of bubbles (Chakrabarti-Bell, Wang, Patel, Weiss, \& Austin, 2013; Chakrabarti-Bell, Wang, \& Siddique, 2014; Ishwarya, Desai, Naladala, \& Anandharamakrishnan, 2017).
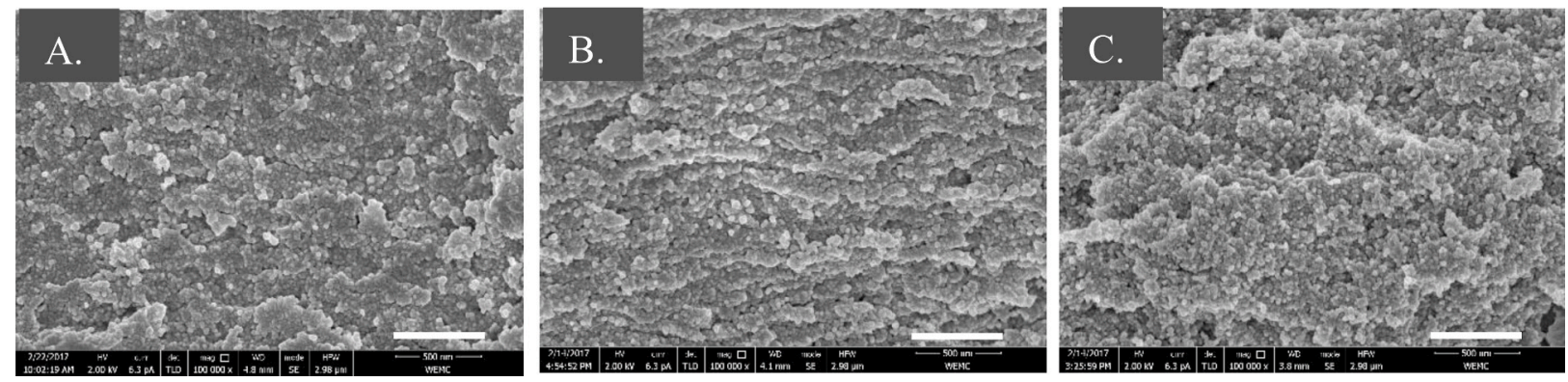

Fig. 4. SEM images of the fractured surface parallel to the shear flow direction of the sheared calcium caseinate materials. The samples are made of $(A) 100 \% \mathrm{H}_{2} \mathrm{O}$; (B) $50 \% \mathrm{D}_{2} \mathrm{O}$ and (C) $100 \% \mathrm{D}_{2} \mathrm{O}$. Scale bars indicate $500 \mathrm{~nm}$.
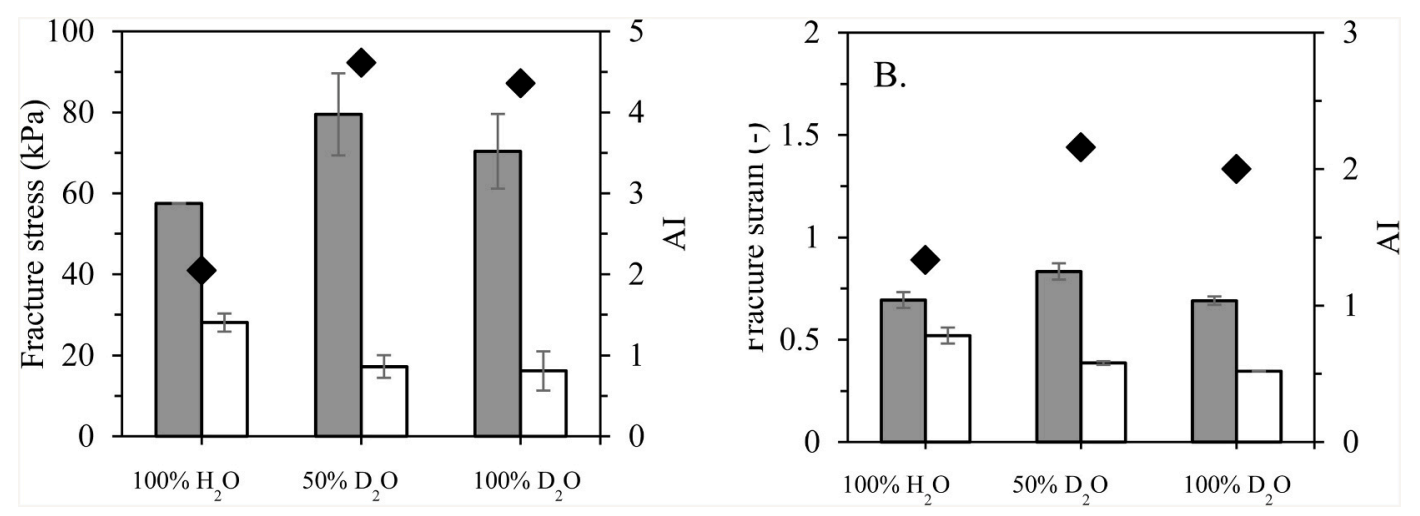

Fig. 5. Tensile properties: (A) fracture stress $\sigma$, (B) fracture strain $\varepsilon$ of sheared calcium caseinate materials $\left(100 \% \mathrm{H}_{2} \mathrm{O}, 50 \% \mathrm{D}_{2} \mathrm{O}\right.$ and $\left.100 \% \mathrm{D}_{2} \mathrm{O}\right)$ deformed parallel (filled bars) and perpendicular (open bars) to the shear direction. The error bars for the mechanical properties are \pm standard deviation; where not visible, they were smaller than the marker used. The anisotropy index (AI, diamonds) is the ratio between the average values measured in the parallel and perpendicular directions. 

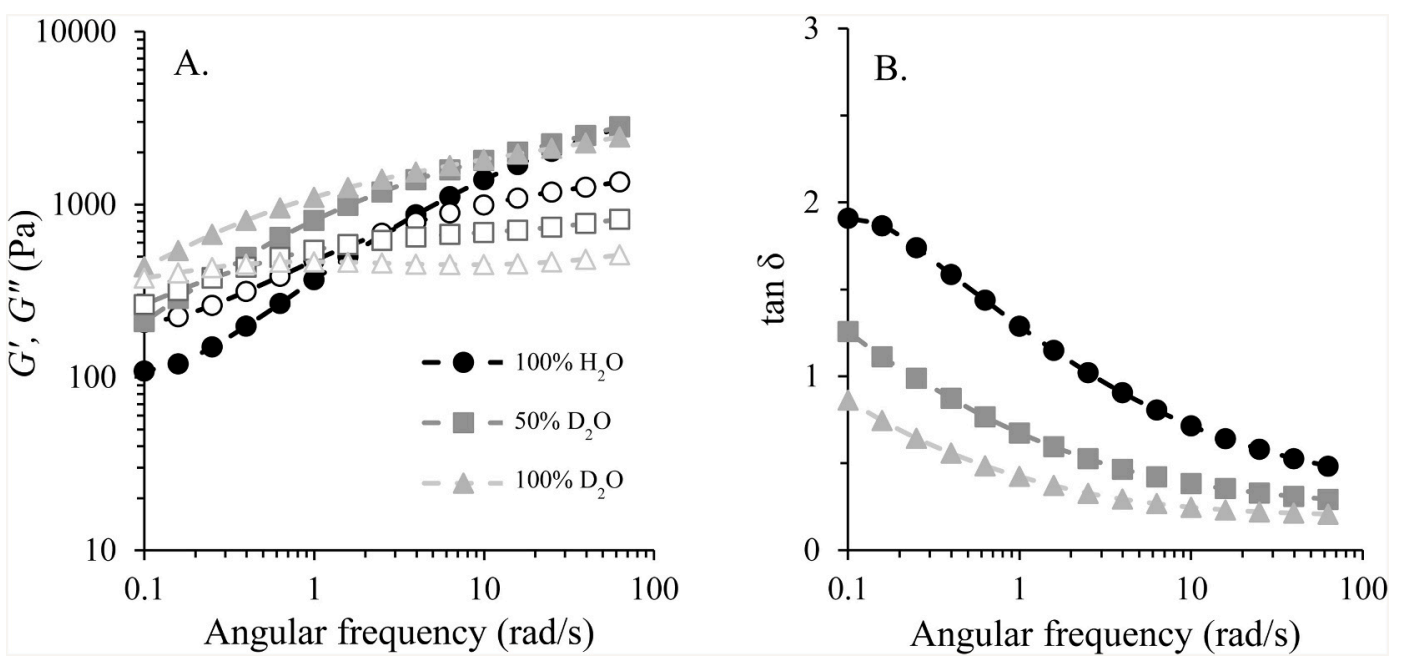

Fig. 6. (A) Storage modulus $G^{\prime}$ (closed symbols) and loss modulus $G^{\prime \prime}$ (open symbols) as a function of angular frequency of calcium caseinate-maltodextrin dispersions. (B) Tangent of phase shift $\tan \delta$ as a function of angular frequency. The lines are guide to the eye.

\section{Conclusions}

The creation of fibre structures within proteins is important, as these structures are promising candidates for the next generation of meat analogues. The use of $\mathrm{D}_{2} \mathrm{O}$ promotes the fibre formation of roller-dried calcium caseinate upon shearing. $\mathrm{D}_{2} \mathrm{O}$ leads to increased calciumprotein interactions and more compact protein structure on molecular level. This results in a more elastic dispersion with longer relaxation time, which makes it more prone for shear alignment. The increased elasticity of the calcium caseinate dispersion also enhanced air inclusion in the protein dispersion. With $\mathrm{D}_{2} \mathrm{O}$, air was included as large and deformed air bubbles that contributed to the fibrous appearance and a greater mechanical anisotropy of the sheared material. These results indicated that the elasticity of the dispersion is important for fibre formation in roller-dried calcium caseinate. This study also draws attention to the solvent quality effects. This suggests on one hand that it is possible through adjusting solvent quality, it is possible to make fibrous materials that were not created when using water, but on the other hand it shows that results obtained with small-angle neutron scattering or nuclear magnetic resonance techniques that used $\mathrm{D}_{2} \mathrm{O}$ as solvent to enhance the quality of the measured should be interpreted carefully.

\section{Declaration of competing interest}

None.

\section{Acknowledgements}

This project is supported from the China Scholarship Council (201406820015), the independent research project program of State Key Laboratory of Food Science and Technology, Jiangnan University (SKLF-ZZB-202012) and the Fundamental Research Funds for the Central Universities (JUSRP52023A). The authors thank Friesland Campina for kindly supplying the protein ingredients, and Jarno Gieteling for technical support.

\section{References}

Bouchoux, A., Ventureira, J., Gésan-Guiziou, G., Garnier-Lambrouin, F., Qu, P., Pasquier, C., ... Cabane, B. (2015). Structural heterogeneity of milk casein micelles: A SANS contrast variation study. Soft Matter, 11(2), 389-399. https://doi.org/ $10.1039 / \mathrm{c} 4 \mathrm{sm} 01705 \mathrm{f}$

Chakrabarti-Bell, S., Wang, S., Patel, M. J., Weiss, R. M., \& Austin, P. J. (2013). Bubbles in chapatti doughs. Journal of Cereal Science, 57, 504-513.
Chakrabarti-Bell, S., Wang, S., \& Siddique, K. H. M. (2014). Flour quality and disproportionation of bubbles in bread doughs. Food Research International, 64, 587-597. https://doi.org/10.1016/j.foodres.2014.07.025

Chakrabarti, G., Kim, S., Gupta, M. L., Barton, J. S., \& Himes, R. H. (1999). Stabilization of tubulin by deuterium oxide. Biochemistry, 38, 3067-3072. https://doi.org/ 10.1021/bi982461r

Cioni, P., \& Strambini, G. B. (2002). Effect of heavy water on protein flexibility. Biophysical Journal, 82, 3246-3253. https://doi.org/10.1016/S0006-3495(02) 75666-X

Dekkers, B. L., Nikiforidis, C. V., \& van der Goot, A. J. (2016). Shear-induced fibrous structure formation from a pectin/SPI blend. Innovative Food Science \& Emerging Technologies, 36, 193-200.

Efimova, Y. M., Haemers, S., Wierczinski, B., Norde, W., \& van Well, A. A. (2007). Stability of globular proteins in H2O and D2O. Biopolymers, 85, 392-406. https:// doi.org/10.1002/bip

Evans, M. T. A., Phillips, M. C., \& Jones, M. N. (1979). The conformation and aggregation of bovine $\beta$-casein A. II. Thermodynamics of thermal association and the effects of changes in polar and apolar interactions on micellization. Biopolymers, 18, 1123-1140.

Ishwarya, S. P., Desai, K. M., Naladala, S., \& Anandharamakrishnan, C. (2017). Braninduced effects on the evolution of bubbles and rheological properties in bread dough. Journal of Texture Studies, 48, 415-426. https://doi.org/10.1111/jtxs.12244

Lopez-Rubio, A., \& Gilbert, E. P. (2009). Neutron scattering: A natural tool for food science and technology research. Trends in Food Science \& Technology, 20(11-12), 576-586. https://doi.org/10.1016/j.tifs.2009.07.008

Manski, J. M., van Riemsdijk, L. E., Boom, R. M., \& van der Goot, A. J. (2007a). Importance of intrinsic properties of dense caseinate dispersions for structure formation. Biomacromolecules, 8, 3540-3547.

Manski, J. M., van der Goot, A. J., \& Boom, R. M. (2007b). Advances in structure formation of anisotropic protein-rich foods through novel processing concepts. Trends in Food Science \& Technology, 18, 546-557.

Manski, J. M., van der Goot, A. J., \& Boom, R. M. (2007c). Formation of fibrous materials from dense calcium caseinate dispersions. Biomacromolecules, 8, 1271-1279.

Oakenfull, D., \& Scott, A. (2003). Gelatin gels in deuterium oxide. Food Hydrocolloids, 17, 207-210. https://doi.org/10.1016/S0268-005X(02)00053-X

Sasisanker, P., Oleinikova, A., Weingärtner, H., Ravindra, R., \& Winter, R. (2004). Solvation properties and stability of ribonuclease A in normal and deuterated water studied by dielectric relaxation and differential scanning/pressure perturbation calorimetry. Physical Chemistry Chemical Physics, 6, 1899-1905. https://doi.org/ 10.1039/b314070a

Schreuders, F. K. G., Dekkers, B. L., Bodnár, I., Erni, P., Boom, R. M., \& van der Goot, A. J. (2019). Comparing structuring potential of pea and soy protein with gluten for meat analogue preparation. Journal of Food Engineering, 261, 32-39.

Sheu, S. Y., Schlag, E. W., Selzle, H. L., \& Yang, D. Y. (2008). Molecular dynamics of hydrogen bonds in protein-D20: The solvent isotope effect. Journal of Physical Chemistry A, 112, 797-802. https://doi.org/10.1021/jp0771668

Tian, B., Garcia Sakai, V., Pappas, C., van der Goot, A. J., \& Bouwman, W. G. (2019). Fibre formation in calcium caseinate influenced by solvent isotope effect and drying method - a neutron spectroscopy study. Chemical Engineering Science, 207, $1270-1277$.

Tian, B., Wang, Z., de Campo, L., Gilbert, E. P., Dalgliesh, R. M., Velichko, E., et al. (2020). Small angle neutron scattering quantifies the hierarchical structure in fibrous calcium caseinate. Food Hydrocolloids, 106, 105912. https://doi.org/ 10.1016/j.foodhyd.2020.105912

Tian, B., Wang, Z., van der Goot, A. J., \& Bouwman, W. G. (2018). Air bubbles in fibrous caseinate gels investigated by neutron refraction, X-ray tomography and refractive microscope. Food Hydrocolloids, 83, 287-295. https://doi.org/10.1016/j. foodhyd.2018.05.006 
Tromp, R. H., \& Bouwman, W. G. (2007). A novel application of neutron scattering on dairy products. Food Hydrocolloids, 21, 154-158. https://doi.org/10.1016/j. foodhyd.2006.02.008

Van der Zalm, E. E. J., Berghout, J. A. M., van der Goot, A. J., \& Boom, R. M. (2012). Starch-gluten separation by shearing: Influence of the device geometry. Chemical Engineering Science, 73, 421-430. https://doi.org/10.1016/j.ces.2012.02.009

Wang, Z., Dekkers, B. L., Boom, R., \& van der Goot, A. J. (2019). Maltodextrin promotes calcium caseinate fibre formation through air inclusion. Food Hydrocolloids, 95, 143-151. https://doi.org/10.1016/j.foodhyd.2019.04.028
Wang, Z., Dekkers, B. L., \& van der Goot, A. J. (2020). Process history of calcium caseinate affects fiber formation. Journal of Food Engineering, 275, 109866.

Wang, Z., Tian, B., Boom, R., \& van der Goot, A. J. (2019a). Air bubbles in calcium caseinate fibrous material enhances anisotropy. Food Hydrocolloids, 87, 497-505.

Wang, Z., Tian, B., Boom, R., \& van der Goot, A. J. (2019b). Understanding the role of air and protein phase on mechanical anisotropy of calcium caseinate fibers. Food Research International, 121, 862-869. https://doi.org/10.1016/j. foodres.2019.01.009 